\title{
Застосування тактики “damage control" у хірургічному лікуванні постраждалих із тяжкою абдомінальною травмою
}

\begin{abstract}
Мета роботи: обгрунтувати доцільність застосування тактики “damage control” у хірургічному лікуванні постраждалих із тяжкою поєднаною абдомінальною травмою.

Матеріали і методи. Проаналізовано результати лікування 28 постраждалих із тяжкими поєднаними травмами органів черевної порожнини. Середній вік пацієнтів склав 39 років (18-66 років), середня оцінка ступеня тяжкості ушкодження за шкалою ISS становила 23 бали. 3 28-ми постраждалих 19 пацієнтів зазнали травми печінки, в тому числі 6 - 3 поєднаними ушкодженнями, 13 - з ізольованими; 9 - з тяжкими поєднаними ушкодженням порожнистих органів та брижових структур. Усі хворі госпіталізовані у стані шоку. 3 IV ступенем тяжкості за шкалою ISS було 22 особи, з V ступенем - 8. Середній показник крововтрати становив у середньому 1200 мл (від 1000 до 2700 мл). Враховуючи тяжкий стан постраждалих, який погіршувався під час проведення операційного втручання, відносно них застосовувалась багатоетапна хірургічна тактика “damage control”. Результати досліджень та їх обговорення. Виконання повноцінного хірургічного лікування у 28-ми пацієнтів основної групи при тяжкій абдомінальній травмі і завчасно запланованої “покрокової” тактики з урахуванням ступеня тяжкості стану постраждалого, об’єму і тяжкості ушкодження органів черевної порожнини з наявністю стійкої коагулопатії, гіпотермії, ацидозу дозволило нам отримати позитивні результати застосування удосконаленої тактики “damage control”. Якщо в контрольній групі летальність серед пацієнтів, яким виконані первинні операції в повному об’ємі, склала 48 \%, то в основній групі 27 \%, що є важливим аргументом на користь подальшого застосування запропонованої тактики в практику хірургічних стаціонарів.
\end{abstract}

Ключові слова: тяжка поєднана абдомінальна травма; тактика “damage control”.

Постановка проблеми і аналіз останніх досліджень та публікацій. Збільшення техногенних і природних катастроф, військових конфліктів призводить у 50-60 \% випадків до поєднаних і множинних ушкоджень органів і систем людини $[1,2]$. Особливою тяжкістю виділяються ушкодження органів черевної порожнини, частка яких у загальній структурі хірургічної травми складає від 1,5 до $18 \%$ всіх травм мирного часу і понад 10 \% у локальних війнах. Для позитивного ефекту хірургічного лікування тяжких абдомінальних ушкоджень має значення термін надання допомоги, послідовність та об'єм оперативних втручань $[2,3]$.

Оцінка пограничних станів дала поштовх наступному етапу розвитку тактики хірургічного лікування постраждалих із політравмою - damage control surgery (DCS) - тактики етапного лікування ушкоджень та їх контролю. На сьогодні показано, що при застосуванні тактики “damage control” у травмованих пацієнтів операційна крововтрата знижується в 10 разів та спостерігається значно менший травмуючий вплив операційного втручання у таких пацієнтів та кількість післяопераційних ускладнень $[4,5]$.

Автори, які використовують тактику “damage control”, вказують на покращення безпосередніх і віддалених результатів хірургічного лікування постраждалих із тяжкою домінуючою абдоміналь- ною травмою та декомпенсованою крововтратою у 60 \% спостережень [6, 7].

Таким чином, виконання повторних запрограмованих оперативних втручань у постраждалих 3 абдомінальною травмою, оптимізація допомоги на догоспітальному етапі, створення спеціалізованих хірургічних центрів дозволить покращити ситуацію $з$ надання медичної допомоги таким пацієнтам.

Мета роботи: обгрунтувати доцільність застосування тактики “damage control” у хірургічному лікуванні постраждалих з тяжкою поєднаною абдомінальною травмою.

Матеріали і методи. Під нашим спостереженням в ОКУ “Лікарня швидкої медичної допомоги” м. Чернівці з 2008 по 2019 рр. знаходилося 28 постраждалих з тяжкими поєднаними травмами органів черевної порожнини. Середній вік пацієнтів склав 39 років (18-66 років), середня оцінка ступеня тяжкості ушкодження за шкалою ISS становила 23 бали. 3 28-ми постраждалих 19 пацієнтів зазнали травми печінки, в тому числі 6 - 3 поєднаними ушкодженнями, 13 - з ізольованими; 9 - 3 тяжкими поєднаними ушкодженням порожнистих органів та брижових структур. Усі хворі госпіталізовані у стані шоку. 3 IV ступенем тяжкості за шкалою ISS було 22 особи, з V ступенем - 8. Середній показник крововтрати становив у середньому 1200 мл (від 1000 до 2700 мл). Враховуючи тяжкий стан по- 
страждалих, який погіршувався під час проведення операційного втручання, відносно них застосовувалась багатоетапна хірургічна тактика.

У прийнятті тактичного рішення щодо застосування багатоетапної лапаротомії враховували наступні критерії: 1) визначення і відбір пацієнтів для виконання операцій типу “damage conrol”; 2) переоцінка під час операції хірургічної ситу- ації в конкретного постраждалого; 3) реабілітація в палаті інтенсивної терапії внаслідок особливостей, що виникли в післяопераційному періоді; 4) кінцеві хірургічні заходи та маніпуляції в операційній за умов повторних операцій; 5) реконструкція передньої черевної стінки в результаті ускладнень, що розвинулися в пізньому післяопераційному періоді (табл. 1).

Таблиця 1. Алгоритм рішення щодо застосування операції "damage control"

\begin{tabular}{|c|l||}
\hline \hline Етап лікування & \multicolumn{1}{|c|}{ Критерії відбору постраждалих } \\
\hline I & Визначення показань до багатоетапного лікування \\
\hline II & $\begin{array}{l}\text { Ревізія під час операційного втручання та оцінка хірургічної ситуації з визначення } \\
\text { показань для скорочення об’єму операцій }\end{array}$ \\
\hline III & Відновлення фізіологічних функцій у хірургічній палаті інтенсивної терапії \\
\hline IV & Повернення пацієнта в операційний блок для завершальних хірургічних заходів \\
\hline V & Визначення показань до реконструкції черевної стінки \\
\hline
\end{tabular}

Ключовими моментами для застосування концепції “damage control” визначали шляхом необхідності її застосування, а під час операційного втручання - максимально швидко зупинити внутрішньочеревну кровотечу та ліквідувати можливе мікробне забруднення очеревинної порожнини. При цьому за розвитку коагулопатичної кровотечі переривання первинної лапаротомії було єдиним шансом до порятунку постраждалого. Тому рішення перервати операцію необхідно приймати якомога раніше, тоді коли кінцеве відновлення ушкодження не буде компенсоване фізіологічними резервами постраждалого або обмеженні технічні можливості.

Результати досліджень та їх обговорення. У хірургічному лікуванні абдомінальної травми кінцевий контроль ефективності і відновлення у постраждалих ушкоджень доцільно виконувати одномоментно за умов проведення первинного операційного втручання. Проте фізіологічні порушення та шоковий стан спричиняють високу летальність. 3 іншої сторони - виконання повторних операційних втручань у таких пацієнтів зумовлене зривом компенсаторних механізмів, розвитком дихальних розладів, легеневими та серцево-судинними ускладненнями, що істотно обмежує виконання загальноприйнятого етапного лікування.

За наявності масивної кровотечі, терапевтичну тампонаду виконували до розвитку масивної, неспинної кровотечі (III-IV ст.); тяжке ушкодження (ISS > 35); гіпотензія (шок тривалістю понад 70 хв; САТ <60 мм рт. ст.); гіпотермія $\left(\mathrm{t}^{\circ}<34{ }^{\circ} \mathrm{C}\right)$, коагулопатія (протромбіновий час > 19 хв, АЧТВ $>60$ хв); ацидоз (рН < 7,2) та ризик декомпенсації супутніх захворювань (III-IV ст.). У ряді випадків ще до виконання лапаротомії ми передбачали тампонаду черевної порожнини як перший етап лікування. Вважали, що незалежно від джерела кровотечі швидкий гемостаз має першочергове значення. Він досягався як лігуванням судин, їх прошиванням, коагуляцією, так і тампонадою за зазначеними показаннями.

Виконання одномоментного хірургічного втручання в розширеному об’ємі як за даними А. Е. Войновского (2002), G. L. Carboni et al. (1999), так i нашими даними завжди призводить до смерті пацієнта.

Питання щодо переривання лапаротомії або повної корекції розчавлених ушкоджень вирішували індивідуально спільно з анестезіологом.

Наводимо опис застосування операції “damage control” за нашими напрацюваннями при тяжких травмах печінки, як найбільш показову.

I етап лікування. Визначення показань до багатоетапного лікування. Значні ушкодження печінки особливо вимагають доцільності застосування тактики “damage control”, яка передбачає скорочення терміну первинної операції та виконання у повному обсязі заходів із виведення пацієнтів із критичних загрозливих життю станів.

Не менш важливим чинником, що впливає на переривання первинної лапаротомії, вважаємо визначення прогностичної оцінки ризику коагулопатії, що безпосередньо загрожує життю постражда- 
лого. До таких предикторів відносили підвищення протромбінового числа більш ніж у 2 рази (2 p $>\mathrm{N})$; частково протромбінового часу у 2 рази (2 p>N); значна тяжкість ушкодження (ISS > 25=7,7 (1,538,8); SBP<70 Hg=5,8/1,2-28,2); рН артеріальної крові $<7,10=12,8(2,4-64,0)$; центральна температура $\mathrm{t}<34^{\circ} \mathrm{C}=8,7(1,8-41,8)$. Наявність зазначених чинників у постраждалих із коагулопатією вимагали вивчення вірогідності розвитку цього ускладнення за окремими показниками (табл. 2).

Таблиця 2. Вірогідність розвитку коагулопатії, що загрожує життю з урахуванням окремих показників

\begin{tabular}{|c|c|c|}
\hline \multirow{2}{*}{$\begin{array}{c}\text { Чинники ризику } \\
\text { коагулопатичної кровотечі }\end{array}$} & \multicolumn{2}{|c|}{ Вірогідність життєзагрожувальної коагулопатії (\%) } \\
\hline & літературні дані & наші дані \\
\hline Відсутність таких & 1 & 1 \\
\hline ISS $>25$ & 10 & 11 \\
\hline ISS $>25+\mathrm{SBP}<70 \mathrm{Hg}$ & 39 & 49 \\
\hline ISS $>25+\mathrm{pH}<7,10$ & 58 & 64 \\
\hline ISS $>25+t<34^{\circ} \mathrm{C}$ & 49 & 59 \\
\hline ISS $>25+\mathrm{SBP}<70 \mathrm{Hg}+\mathrm{t}<34^{\circ} \mathrm{C}$ & 85 & 94 \\
\hline ISS $>25+\mathrm{SBP}<70 \mathrm{Hg}+\mathrm{pH}<7,10+\mathrm{t}<34^{\circ} \mathrm{C}$ & 280 & 277 \\
\hline Коефіцієнт ризику коагулопатичної кровотечі & 98 & 79 \\
\hline
\end{tabular}

Примітки: ISS - шкала тяжкості ушкодження; SBP - систолічний кров’яний тиск; рН - артеріальної крові.

Розбіжність аналізу зазначених показників у постраждалих, обмеження у часі щодо прийняття рішення розраховували за визначеним універсальним коефіцієнтом ризику розвитку післятравматичної коагулопатії, величину якого розраховували за розробленою формулою:

$$
\mathrm{K}_{\mathrm{p}}=\frac{\mathrm{a}+\mathrm{B}+\Gamma}{6},
$$

де а - чинник ISS >25 = 0,1;

б - чинник SBP $<70 \mathrm{Hg}=0,35$;

в - чинник $\mathrm{pH}<7,10=0,1$;

г - чинник $\mathrm{t}<34{ }^{\circ} \mathrm{C}=0,05$.

Закриття черевної порожнини на першому етапі операцій “damage control” виконували без ушивання апоневрозу з метою попередження розвитку синдрому абдомінального стиснення. При цьому накладали тільки цапки за методикою Бена Тубе (рис. 1), а у випадках вираженого набряку органів очеревинної порожнини застосовували фіксацію поліетиленовою плівкою за краї шкіри або пришивали до шкіри безперервним швом.

II етап лікування. До переведення постраждалого із операційної в палату інтенсивної терапії враховували наступні питання: коли переводити пацієнта; чи зберігається залишкова кровотеча; чи є необхідність у тампонуванні черевної порожнини; чи є необхідність у проведенні цих заходів взагалі. Слід врахувати і те, що швидке виконання реанімаційних заходів є доцільним за умов неефективності гемостазу. Оскільки кровотеча, яка триває, поглиблює порушення, які зумовлені “порочним колом” крововтрати. Тому проводили моніторинг виділень з черевної порожнини, показників згортальної системи крові під дією медикаментозної корекції, а також боротьби з гіпотермією шляхом загального зігрівання пацієнта. 3 цією ме-

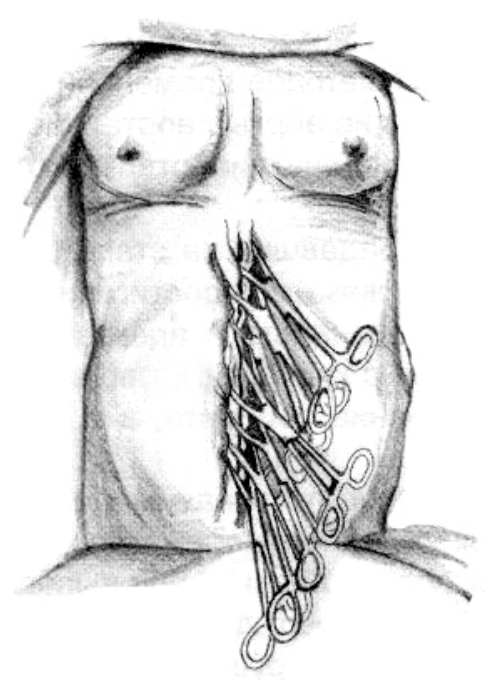

Рис. 1. Накладання на шкіру цапок за методикою Бена Тубе (В. В. Бойко, В. П. Польовий, 2007). 
тою застосовуємо обкладання постраждалого теплими грілками. Для корекції кислотно-лужного стану призначали бікарбонат натрію (при $\mathrm{pH}<7,2$ ) та гемокомпонентну терапію.

Через 30-50 хвилин після проведення інтенсивної терапії та стабілізації основних систем гомеостазу черевну порожнину розкривали і проводили їі ревізію. У двох випадках тампони видаляли повністю, в одному випадку проводили додаткове тампонування сумнівних за гемостазом джерел кровотечі, заміну тампонів на гемостатичну губку.

Ушкодження порожнистих органів усували шляхом накладання швів чи первинною резекцією органа. Ми проаналізували матеріал з використання тактики “damage control” у 6-ти постраждалих із травматичним ушкодження тонкої кишки. При загрозі коагулопатичної кровотечі формували однорядні шви або резекцію кишки без ії̈ анастомозування для запобігання подальшому інфікуванню черевної порожнини. Залишається дискусійним питання щодо пропозиції I. G. Parreira et al. (2002) H. M. Foy et al. (2003), P. V. Giannoudis (2003) про відкладення на третій етап резекції ушкодженої кишки. На нашу думку, запобігання інфікуванню черевної порожнини є одним 3 першочергових завдань, а накладання анастомозів може бути відтермінованим на 24-72 год з метою стабілізації гемодинамічних показників і виведення постраждалого із стану травматичного шоку.

Використання тактики “damage control” дозволяє накладати первинні анастомози при пораненні також товстої кишки зі сприятливими віддаленими результатами. У разі необхідності формування колостоми, на думку Ноеу B. et al. (2002), її необхідно виводити на черевну стінку якомога латеральніше. Хоч “бічна” колостома зумовлює більший дискомфорт для пацієнта, але при такому положенні нориці проведення наступних релапаротомій технічно більше сприятливо. В оперованих нами чотирьох постраждалих з ушкодженням товстої кишки на фоні травматичної хвороби наслідки були наступні: двоє померли в ранньому післяопераційному періоді, а двом проведенні реконструктивні операційні втручання після стабілізації основних фізіологічних параметрів через 72 год 3 моменту отримання травми з накладенням анастомозів.

III етап лікування. На даному етапі лікування головним завданням було відновлення фізіологічних параметрів організму постраждалого в палаті інтенсивної терапії. Під постійним моніторингом кислотно-лужного стану крові, температури тіла, гемодинаміки, біохімічних показників крові, похвилинного діурезу проводили оцінку ефективності III етапу лікування. Проводили інтенсивну підтримку до повної компенсації показників об’єму циркулюючої крові, гемоглобіну та гематокриту крові, зігрівання пацієнта; механічну вентиляцію легень.

Одним із завдань III етапу лікування є зниження внутрішньочеревного тиску, чого можна досягти зняттям цапок з передньої черевної стінки. У випадку некупірованої інтраабдомінальної гіпертензії показано виконання релапаротомії за життєвими показаннями. Термінове операційне втручання також доцільно проводити пацієнтам з кровотечою, яка триває, незважаючи на корекцію згортальної системи крові, гіпотермії та ацидозу шляхом ангіографічної суперселективної емболізації кровоточивих судин. Всі інші пацієнти підлягають повторній лапаротомії не раніше 24 год від моменту первинної операції для видалення тампонів, згустків крові, шлунково-кишкової та судинної реконструкції, декомпресії кишечника і забезпеченя ентерального харчування.

Думка щодо термінів виконання повторних операційних втручань у літературі різна. На нашу думку, оптимальність терміну проведення релапаротомії через 48-72 год прийнятна тим, що за цей час стабілізуються метаболічні порушення, а також не встигає розвинутися системний запальний синдром - сепсис.

IV етап лікування передбачає повернення постраждалого в операційний блок для повної реконструктивної хірургічної корекції органів і систем черевної порожнини, які травмовані. Під час проведення операційного втручання видаляли тампони, залишені в черевній порожнині, перевіряли герметичність ушитих кишкових ран і сформованих анастомозів. Після ретельної санації черевної порожнини антисептичними засобами черевну порожнину зашивали.

V eman лікування. На даному етапі проводиться пошук методик закриття черевної стінки. Проблема виникає у постраждалих, яким виконували множинні відтерміновані релапаротомії, повна або часткова втрата передньої черевної стінки внаслідок травми або інфекції. Характеристика способів закриття черевної порожнини представлена в таблиці 3.

Таблиця 3. Операційні втручання із закриття передньої черевної стінки

\begin{tabular}{|l|c||}
\hline \multicolumn{1}{|c|}{ Вид операції } & Кількість хворих \\
\hline Пошарове ушивання & 5 \\
\hline Наскрізні шви на прокладках & 14 \\
\hline Ушивання тільки шкіри & 6 \\
\hline Алопластичні методи укриття & 3 \\
\hline
\end{tabular}


Закриття черевної порожнини істотно залежить від конкретної хірургічної ситуації. У випадках, коли апоневроз не може бути стягнутий через натяг, принциповим вважаємо ушивання тільки шкіри, оскільки наявний стан евентерації сприяє роз- витку нориць, що підтверджують А. Schachtrupp et al. (2003), J. M. Nicholas et al. (2005), S. Richard et al. (2005). У трьох випадках застосовували послаблювальні розрізи по внутрішній поверхні фаланг бокових каналів (рис. 2).

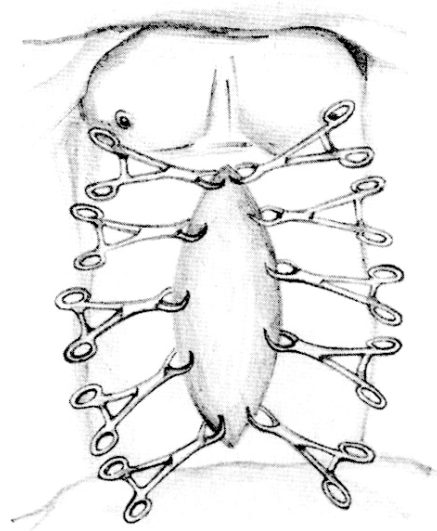

A

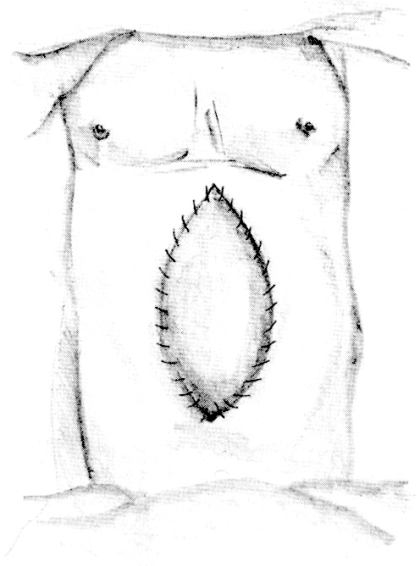

Б

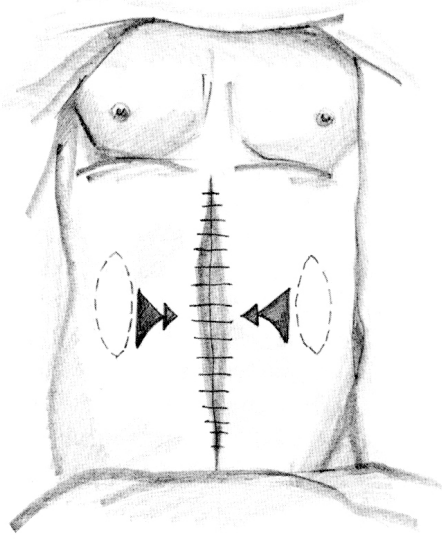

B

Рис. 2. Метод тимчасового закриття органів черевної порожнини: А - з фіксацією поліетиленової плівки до країв шкіри цапками; Б - з ушиванням до країв рани; В - розсічення очеревини та апоневрозу зі сторони черевної порожнини (Бойко В. В., Польовий В. П., 2007).

У деяких ситуаціях така методика виявилася неефективною. При збереженому великому сальнику його вкладали на органи черевної порожнини та фіксували до передньої черевної стінки, а потім виконували алопластику передньої черевної стінки поліпропіленовою сіткою “ЕTICON”. Шкіра при цьому ушивається звичайним способом. У спостереженнях, коли ушивання передньої черевної стінки було неможливим ні одним з названих способів, рану вели відкритим способом під мазьовими тампонами. Після ії̈ очищення накладали вторинні шви.

Висновки. Таким чином, тактика "damage control” у хірургічному лікуванні постраждалих з абдомінальною травмою використана нами у 28-ми пацієнтів основної групи при тяжкій абдомінальній травмі 3 летальністю 27 \%, тоді як

\section{СПИСОК ЛІТЕРАТУРИ}

1. Бойко В. В. Тактика “damage control” у пострадавших при тяжелой сочетанной травме органов брюшной полости / В. В. Бойко, П. Н. Замятин, С. Б. Пеев // Клінічна хірургія. - 2014. - № 12. - С. 5-9.

2. Хоменко I. П. Застосування тактики “damage control” у тяжких поранених і потерпілих в умовах бойових дій і мирного часу / І. П. Хоменко, В. П. Майданюк // Шпитальна хірургія. - 2014. - № 2. - С. 92-95.

3. Martin J. L. Pedestrian injury patterns according to car and ca- в контрольній групі даний показник склав $48 \%$, що є важливим аргументом на користь подальшого застосування запропонованої тактики в практику хірургічних стаціонарів. Проте, на думку М. М. Абакумова та співавт. (2007), концепцію “damage control” не можна вважати принципово новою і вона призначена тільки для обмеженого контингенту постраждалих, оскільки не вичерпує всіх можливих варіантів лікування пацієнтів із множинними та поєднаними ушкодженнями живота.

Перспективи подальших досліджень. У подальших дослідженнях будуть розроблені чіткі критерії щодо аргументованих показань для застосування тактики “damage control” у хірургічному лікуванні пацієнтів з поєднаними абдомінальними пошкодженнями.

sualty characteristics in France / J. L. Martin, A. Lardy, B. Laumon // Ann. Adv. Automot. Med. - 2011. - No. 55. - P. 137-146. 4. Pattern, severity and circumtances of injuries sustained in road traffic accidents: a tertiary care hospital-based study / R. Singh, H. K. Singh, S. C. Gupta, Y. Kumar // Indian J. Community Med. - 2014. - Vol. 39 (1). - P. 30-34.

5. Skinner D. ABC of major trauma / D. Skinner, P. Driscoll. 4th edition. - BMJ Publishing Group, 2013 - 238 p. 10. Trauma guideline manual [Electronic resource] / Trauma surgery service 
trauma center mission hospitals Asheville, NC 2007. - Mode of access : www.mission-health.org/sites/.../705_0.pd f - Title from the screen.

6. Gupta M. Selective use of computed tomography compared with routine whole body imaging in patients with blunt trauma /

\section{REFERENCES}

1. Boyko, V.V., Zamyatyn, P.N., \& Peev, S.B. (2014). Taktyka "damage control" u postradavshykh pry tyazheloy sochetannoy travme organov bryushnoy polosti [Damage control tactics in victims of severe concomitant trauma of the abdominal organs]. Klinichna khirurhiia - Clinical Surgery, 12, 5-9 [in Russian].

2. Khomenko, I.P, \& Maydanyuk, V.P. (2014). Zastosuvannia taktyky "damage control” u vazhkykh poranenykh i poterpilykh v umovakh boiovykh dii i myrnoho chasu [Application of "damage control" tactics in severely wounded and injured in conditions of hostilities and peacetime]. Shpytalna khirurhiia - Hospital Surgery, 2, 92-95 [in Ukrainian].

3. Martin, J.L., Lardy, A., \& Laumon, B. (2011). Pedestrian injury patterns according to car and casualty characteristics in France. Ann. Adv. Automot. Med., 55, 137-146.

4. Singh, R., Singh, H.K., Gupta, S.C., \& Kumar, Y. (2014). Pat-
M. Gupta, D. L. Schriger, J. R. Hiatt [et al.] // Ann. Emerg. Med. - 2011. - Vol. 58 (5). - P. 407-416.

7. Natarajan B. FAST scan: is it worth doing in hemodynamically stable blunt trauma / B. Natarajan, P. K. Gupta, S. Cemaj, M. Sorensen // Surgery. - 2010. - Vol. 148 (4). - P. 695-700.

tern, severity and circumtances of injuries sustained in road traffic accidents: a tertiary care hospital-based study. Indian J. Community Med., 39 (1), 30-34.

5. Skinner, D., \& Driscoll, P. (2007). ABC of major trauma. 4th edition. BMJ Publishing Group, 2013. Trauma guideline manual.Trauma surgery service trauma center mission hospitals Asheville, NC 2007 Retrieved from: www.mission-health.org/ sites/.../705_0.pdf.

6. Gupta, M., Schriger, D.L., \& Hiatt, J.R. (2011). Selective use of computed tomography compared with routine whole body imaging in patients with blunt trauma. Ann. Emerg. Med., 58 (5), 407-416.

7. Natarajan, B., Gupta, P.K., Cemaj, S., \& Sorensen, M. (2010). FAST scan: is it worth doing in hemodynamically stable blunt trauma. Surgery, 148 (4), 695-700.

Отримано 25.03.2020

Електронна адреса для листування: doctorvictor@i.ua

\author{
V. P. POLYOVY, S. I. RAILYANU, A. S. POLYANITSA, I. G. CHEPEGA
}

Bukovinian State Medical University

\title{
APPLICATION OF "DAMAGE CONTROL" TACTICS IN SURGICAL TREATMENT OF PATIENTS WITH HEAVY ABDOMINAL TRAUMA
}

The aim of the work: to substantiate the feasibility of using "damage control” tactics in the surgical treatment of victims with severe combined abdominal trauma.

Materials and Methods. The results of treatment of 28 victims with severe combined injuries of abdominal organs were analyzed. The average age of the patients was 39 years (18-66 years), the average grade of severity of injury on the ISS scale was 23 points. Of the 28 victims, 19 patients suffered liver injuries, including 6 with combined lesions, 13 with isolated ones; 9 - with severe combined damage to the hollow organs and mesenteric structures. All patients were in a state of shock. There were 22 people with severity IV on the ISS scale, with degree V - 8. The average blood loss was on average $1200 \mathrm{ml}$ (from 1000 to $2700 \mathrm{ml}$ ). Given the severe condition of the victims, which worsened during surgery, a multi-stage "damage control” tactic was applied to them.

Results and Discussion. Complete surgical treatment in 28 patients of the main group with severe abdominal trauma and pre-planned "step-by-step" tactics taking into account the severity of the condition of the victim, the volume and severity of damage to the abdominal organs, with the presence of persistent coaguloputopomy the results of advanced damage control tactics. In the control group, the mortality rate among patients who underwent primary surgery in full was $48 \%$, in the main group $27 \%$, which is an important argument for the continued use of the proposed tactics in the practice of surgical hospitals.

Key words: severe combined abdominal trauma; damage control tactics. 


\author{
В. П. ПОЛЕВОЙ, С. И. РАЙЛЯНУ, А. С. ПАЛЯНИЦА, И. Г. ЧЕПЕГА
}

Высшее государственное учебное заведение Украины “Буковинский государственный медицинский университет”

\title{
ПРИМЕНЕНИЕ ТАКТИКИ “DАМАGЕ СОNТRОL” В ХИРУРГИЧЕСКОМ ЛЕЧЕНИИ ПОСТРАДАВІІИХ С ТЯЖЕ.ЛЙ АБДОМИНАЛЬНОЙ ТРАВМОЙ
}

Цель работы: обосновать целесообразность применения тактики “damage control” в хирургическом лечении пострадавших с тяжелой сочетанной абдоминальной травмой.

Материалы и методы. Проанализированы результаты лечения 28 пострадавших с тяжелыми сочетанными травмами органов брюшной полости. Средний возраст пациентов составил 39 лет (18-66 лет), средняя оценка степени тяжести повреждения по шкале ISS составила 23 балла. C 28-ми пострадавших 19 пациентов подверглись травме печени, в том числе 6 - с сочетанными повреждениями, 13 - с изолированными; 9 - с тяжелыми сочетанными повреждением полых органов и брыжеечных структур. Все больные поступали в состоянии шока. C IV степени тяжести по шкале ISS было 22 человека, с V степени - 8. Средний показатель кровопотери составил в среднем 1200 мл (от 1000 до 2700 мл). Учитывая тяжелое состояние пострадавших, которое ухудшалось во время проведения оперативного вмешательства, в отношении них применялась многоэтапная хирургическая тактика “damage control”.

Результаты исследований и их обсуждение. Выполнение полноценного хирургического лечения в 28-ми пациентов основной группы при тяжелой абдоминальной травме и заблаговременно запланированной “пошаговой” тактики с учетом степени тяжести состояния пострадавшего, объема и тяжести повреждения органов брюшной полости с наличием устойчивой коагулопатии, гипотермии, ацидоза позволило нам получить положительные результаты применения усовершенствованной тактики “damage control”. Если в контрольной группе летальность среди пациентов, которым выполнены первичные операции в полном объеме, составила 48 \%, то в основной группе 27 \%, что является важным аргументом в пользу дальнейшего применения предложенной тактики в практику хирургических стационаров.

Ключевые слова: тяжелая сочетанная абдоминальная травма; тактика “damage control”. 